\title{
ANALISIS STRATEGI PEMBELAJARAN ACTIVE KNOWLEDGE SHARING DAN CERAMAH TERHADAP HASIL BELAJAR PENDIDIKAN AGAMA ISLAM
}

\author{
Latifah Hanum \\ Universitas Islam Sumatera Utara (UISU) \\ E-mail: latifah.hanum@ffkip.uisu.ac.id
}

How to Cite:

Hanum, L. (2020). Analisis Strategi Pembelajaran Active Knowledge Sharing dan Ceramah Terhadap Hasil Belajar Pendidikan Agama Islam. Fitrab: Journal of Islamic Education, 1(1). 36-54.

\section{ARTICLE HISTORY \\ Received :30 June 2020 \\ Revised :22 July 2020 \\ Accepted :22 July 2020 \\ Published :25 July 2020}

\section{KEYWORDS:}

Strategy, Active Knowledge Sharing, Learning outcome

\begin{abstract}
The aims of this study are to compare learning outcomes of Islamic Religious Education using active knowledge sharing learning strategies and lecture strategies. This research was conducted at MTs Bina Taruna Marelan with 60 students as the sample in this study. The research method used in this study is a quantitative method with the type of experiment. The main instrument used in data collection is an objective test instrument consisting of 20 questions. The material provided is about Zakat Fitrah and Malls. The comparative analysis used is the $t$ test statistic for two large samples which do not have a relationship with each other. The results showed that learning outcomes using active knowledge sharing learning strategies obtained an average value of 73.50 included in category B (good). While using lecture learning strategies obtained an average value of 62.83 included in category $\mathrm{C}$ (enough). So that the active knowledge sharing learning strategy is more effective by $16.88 \%$ of the lecture learning strategy in improving the learning outcomes of Islamic Religious Education grade VII students of MTs Bina Taruna Marelan.
\end{abstract}

\section{RIWAYAT ARTIKEL}

Diterima : :30 Juni 2020

Direvisi : :22 Juli 2020

Disetujui :22 Juli 2020

Diterbitkan :25 Juli 2020

\section{KATA KUNCI:}

Strategi, Active Knowledge Sharing, Hasil Belajar

\begin{abstract}
ABSTRAK
Tujuan dilaksanakannya penelitian ini ialah untuk membandingkan hasil belajar Pendidikan Agama Islam menggunakan strategi pembelajaran berbagi pengetahuan aktif dan strategi ceramah. Penelitian ini dilakukan di MTs Bina Taruna Marelan dengan 60 siswa sebagai sampel dalam penelitian ini. Metode penelitian yang digunakan dalam penelitian ini ialah metode kuantitatif dengan jenis eksperimen. Instrumen utama yang digunakan dalam pengumpulan data adalah instrumen tes objektif yang terdiri dari 20 pertanyaan. Materi yang diberikan adalah tentang Zakat Fitrah dan Mal. Analisis komparatif yang digunakan adalah statistik uji $\mathrm{t}$ untuk dua sampel besar yang tidak memiliki hubungan satu sama lain. Hasil penelitian menunjukkan bahwa hasil belajar menggunakan strategi pembelajaran berbagi pengetahuan aktif diperoleh nilai rata-rata 73,50 termasuk dalam kategori B (baik). Sedangkan menggunakan strategi pembelajaran ceramah diperoleh hasil nilai rata-rata 62,83 termasuk dalam kategori C (cukup). Sehingga strategi pembelajaran berbagi pengetahuan aktif lebih efektif dengan $16,88 \%$ dari strategi pembelajaran ceramah dalam meningkatkan hasil belajar siswa Pendidikan Agama Islam siswa kelas VII MTs Bina Taruna Marelan.
\end{abstract}




\section{PENDAHULUAN}

Pemilihan strategi pembelajaran merupakan sesuatu yang urgen. Salah satu dasar pemilihan itu terletak pada kemampuan strategi dalam mengembangkan kompetensi peserta didik agar dapat untuk berpikir logis, kritik, dan kreatif (Assingkily \& Mikyal: 2019). Penentuan strategi yang tepat akan dapat menghantarkan siswa pada peningkatan keaktifan dalam proses pembelajaran sehingga ia mampu untuk menyampaikan pendapat, berinteraksi dengan teman-teman lain, bahkan sampai juga mampu untuk memberikan respon terhadap pemikiran siswa dan pemikiran teman lainnya (Assingkily \& Miswar: 2020). Pemilihan stategi yang tepat pun bukan hanya menguntungkan utukk murid saja, namun juga untuk pendidik yang dengan mudah dan nyaman dalam mengajarkan konsep pembelajaranya. (Anita Lie, 2008).

Salah satu jenis strategi pembelajaran yang mampu meningkatkan keaktifan siswa khususnya dalam menanggapi pemikiran temannya ialah strateti Active Knowledge Sharing. Strategi ini merupakan strategi yang basisnya pada sharing pertanyaan, dan mengharapkan peserta didik lain untuk menyampaikan tanggapan terhadap pertanyaan tersebut. Strategi ini membuat siswa mampu untuk berpikir secara cepat, dan mampu membuat siswa untuk kompak bekerjasama dalam memecahkan soal yang ada dan bersama-sama untuk mencari dan menjawabnya. strategi ini biasa dikombinasikan pada pembelajaran dengan metode ceramah, sehingga tujuan adanya strategi ini penyampaian secara ceramah yang dilakukan guru mendapatkan perhatian dari siswa, terutama dalam hal pada rasio siswa yang padat dalam satu ruang. Jika tidak menggunakan strategi ini, penyampaian secara ceramah mungkin akan menyita banyak tenaga pendidik, sebab harus mengeluarkan suara yang begitu kuat untuk mengontrol kondisi kelas dengan jumlah peserta yang cukup banyak.

\section{Penerapan Strategi Active Knowledge} sharing pada proses pembelajaran di MTS Bina Taruna Marelan merupakan satu langkah yang baik dan termasuk bagian dari respon terhadap pembelajaran yang modern dalam bingkai Sistem Pendidikan di Indonesia. Khususnya di Madrasah ini diterapkan dalam bidang studi pendidikan agamaa Islam, yang termasuk bidang studi yang menjadi pelajaran utama dan pendukung bagi pembelajaran laiinya.

Pemutakhiran sistem pembelajaran tentu berdampak pada peningkatan sumber daya manusia. Seiring dengan tuntutan global dan nafas dari pendidikan Islam, bahwa orientasi dari kualitas sumber daya manusia itu terukur dari keselarasan penguasan IPTEK dan IMTAQ, atau dengan kata lain penyelarasan antara pengetahua, spiritual, bahkan moral siswa. Tanpa adanya itu tentu generasi penerus 
Islam tidak akan kokoh dan mampu untuk berdaya saing. (Indianto, D, 2019).

Penerapan strategi active knowledge sharing, tidak hanya memberikan keaktifan pada siswa saja, akan tetapi juga pada guru itu sendiri. Dikatakan demikian, karena sang guru juga akan terpacu untuk mengarahkan siswanya pada kondisi yang aktif dalam belajar. Sehingga jika kedua-duanya (guru dan siswa aktif) maka akan dengan mudah siswa dapat mengaktualisasikan potensi yang ada pada dirinya, sebab selama ini banyak pembelajaran justru malah mengurung potensi yang dimilikinya. Keaktifan antara guru dan siswa juga bermuara pada peningkatan kualitas pembelajaran pendidikan agama Islam, sebab selama ini banyak yang memandang bahwa pendidikan agama islam mengalami penurunan kualitas yang salah satunya terlihat dari kurangnya antusias dan munculnya sikap jenuh siswa dalam mengikuti pembelajaran, dan hal ini rata-rata karena faktor kekurang tepatan dalam pemilihan strategi pembelajaran.

Berdasarkan pengamatan awal yang penulis lakukan di MTS Bina Taruna Marelan, dapat lah dikategorikan bahwa rerata peserta didik tidak antusias dan termotivasi mengikuti proses belajar, dan pada saat guru menerangkan pembelajaran, beberapa siswa malah lebih asyik dengan urusannya sendiri, walaupun dalam kondisi ini guru berusaha untuk mengelola dan mengamankan kelas, namun upaya itu hanya bertahan beberapa waktu saja. Hasil pengamatan penulis menunjukkan bahwa kondisi ini kemungkinan disebabkan karena frekwensi penggunaan metode ceramah yang terlalu sering. Akibatnya penulis mengamati bahwa pada saat pembelajaran berlangsung tidak seorang siswa pun tampak berani untuk mengemukakan pendapat dan melontarkan pertanyaan tanpa di perintah oleh guru. Hal ini tentu membuat jalannya pembelajaran tidak maksimal, bahkan menghambat pencapaian tujuan pembelajaran seperti yang telah direncanakan. Keseluruhan hasil pengamatan awal tersebut dika jika di simpulkan terdapat beberapa maslah utama yakni sebagai berikut: (1) Kurangnya minat belajar siswa pada mata pelajaran pendidikan agama Islam, (2) Sebagian siswa merasa kesulitan mempelajari pelajaran pendidikan agama islam dikarenakan rata-rata pembahasanya menggunakan bahasa arab, (3) kurang variatifnya strategi yang di pergunakan oleh guru saat pembelajaran berlangsung..

Adanya kesenjangan antara idealitas dan realitas pada pembelajaran inilah yang membuat peneliti tertarik untuk melakukan penelitan. Walaupun telah menggunakan metode ceramah tetapi tampaknya memang metode ceramah belum sepenuhnya mampu untuk meningkatkan keaktifan siswa, baik untuk berpikir aktif ataupun untuk bekerjasama dalam tim. Untuk itulah peneliti 
tertarik melakukan penelitian dengan mengujicoba strategi pembelajaran Active Knowledge sharing sebagai solusi untuk mengatasi kesenjangan yang ada. Dalam konteks ini, Satriawati, et.al., (2018) menerangkan bahwa strategi pembelajaran tersebut tepat diberikan kepada anak dalam melatih keterampilan berpikir tingkat tinggi.

\section{KAJIAN TEORI}

\section{Strategi Pembelajaran Ceramah}

Istarani (2011) memaparkan bahwa, strategi pembelajaran ialah suatu rangkaian aktivitas pembelajaran yang harus dipedomani dan dilaksanakan guru dan siswa agar mencapai tujuan pembelajaran. Sanjaya (2008) menerangkan bahwa strategi merupakan suatu paket konten dan prosedur pembelajaran yang dipakai bersamaan untuk menciptakan hasil belajar pada siswa. pengertian yang sederhana dijelaskan oleh Roestiyah (2009), bahwa strategi dimaknai sebagai jalan yang ditemph guru untuk menuju tujuan pembelajaran sebagaimana yang telah di rencanakan.

Active Knowledge Sharing termasuk bagian dari kelompok strategi pembelajaran active learning dimana tujuan dasarnya ialah untuk mengaktifkan peran siswa dalam pembelajaran. Zaini Hisyam (2007) pembelajaran aktif ialah pembelajaran yang menjadikan agar siswa menjadi aktif ikutserta dalam seluruh proses pembelajaran, baik dengan fisik maupun dengan mental.
Fisik berarti menyangkut keterampilannya, sedangkan mental menyangkut keaktifan daya pikir siswa untuk dapat memecahkan masalah. Selain memberikan keaktifan kepada siswa pembelajaran aktif juga dapat memberikan kenyamanan dan kesenangan pada diri siswa.

Pada dasarnya pembelajaran active learning menjadikan siswa menjadi lebih nyaman dalam belajar, sebab dengan strategi tersebut kemampuan siswa terfasilitasi untuk dapat melakukan segala hal yang diinginkannya. Semua bentuk stimulus dan respon dari diri siswa saat pembelajaran berlangung dapat berjalan dengan baik dan lancar. Dengan kondisi itu tentu pembelajaran menjadi sesuatu yang menyenangkan dan tidak memjenuhkan. Pembelajaran yang menjenuhkan tentu akan menghasilkan efek yang tidak bagus diri siswa khususnya bagi mental siswa.

Menurut Silberman (2009), Strategi Active Knowledge Sharing merupakan cara yang optimal untuk mengarahkan perhatian siswa kepada materi pelajaran. Guru dapat memakainya, sebagai alatu ukur sudah sejauhmana pengetahuan siswa, bahkan penggunaan strategi titu juga memperkuat hubungan tim siswa, Strategi itu dapat berjalan antar materi pelajaran ataupun antar beberapa ragam mata pelajaran. Trianto (2010, active knowledge sharing ialah strategi pembelajaran yang penekanannya lebih fokus pada materi pelajaran yang diajarkan, 
dalam hal ini pembelajaran diarahkan kepada berelompok atau membentuk tim belajar untuk saling berbagi ilmu dan pengalaman belajar. Dengan demikian lebih mudah untuk menilai tingkat kemajuan siswa.

Banyak juga yang menjelaskan bahwa srategi pembelajaran ini dikenal sebagai strategi yang polanya saling tukar menukar pengetahuan antara satu siswa dengan siswa lainnya, siswa saling bersama untuk menjawab pertanyaan yang diberikan dan saling bertukar pikiran untuk jawaban tersebut. Artinya dalam kegiatan ini terjadi kerjasama dan kepedulian tim, satu siswa yang sudah mengerti membantu temannya yang tidak mengerti, satu siswa yang memahami membantu temannya untuk dapat memahami. Bahkan teman yang tidak mampu menyelesaikan pertanyaan yang diberikan guru dibantu oleh teman lainnya. Tentu strategi pembelajaran ini sangat ideal bukan hanya meningkatkan kemampuan individu saja, akan tetapi meningkatkan kemampuan sosialnya, terutama dalam hal ini sesame teman satu kelas. Itulah sebabnya strategi ini dikenal degan istilah Kenowledge Sharing (berbagi pengetahuan).

\section{Strategi Pembelajaran Ceramah}

Salah satu strategi dalam pembelajaran konvensional adalah pendekatan verbal, yakni pembelajaran ceramah. Menurut Roestiyah, ceramah merupakan metode mengajar yang dipakai untuk menjelaskan materi ataupun uraian tentang suatu pokok permasalahan atau materi pembelajaran yang disampaikan melalui lisan. Ceramah ini biasa disebut dengan strategi menginformasikan atau strategi lecture sebab strategi ini banya dipakai di perguran tinggi. Pada fungsinya sebenarnya sangat luas, ceramah bukan hanya sekedar menyampaikan pesan saja kepada siswa akan tetapi pada titik tekan tertentu ceramah bisa juga dipakai untuk menjelaskan dan menguraikan sesuatu mengenai satu problematika. Dengan kata lain dari penjelasan di atas, ceramah dapat dimaknai dari dua sisi, dari sisi yang sederhana ceramah cenderung dimaknai sebagai metode penyampai pesan, sedangkan secara luas dapat dimkanai sebagai metode untuk membahas sesuatu hal yang sifatnya bisa saja berbentuk wacana atau problematika (Wina Sanjaya: 2008).

\section{Pembelajaran Konvensionnal} merupakan pembelajaran yang lazim digunakan penddik dalam kegiatan belajar mengajarnya setiap hari di sekolah Dalam hal ini konvensional dapat berupa metode ceramah dan tanya jawab yang bertujuan untuk menjabarkan suatu penjelasan atau uraian terkait dengan topik atau permasalahan yang sedang menjadi pembahasan. Disebut sebagai pembelajaran yag konvensional karena pembelajaran ini sangat sering digunakan oleh guru, dan kegiatan pebelajarannya lebih didominasi oleh guru sebagai pemberi pelajaran, atau 
dengan kata lain model pembelajarannya satu arah, dikatakan demikian karena dalam hal ini siswa lebih bersifat pasif dalam arti lebih banyak untuk mendengarkan penjelasan guru. Siswa lebih banyak duduk mendengarkan kajian yang disampaikan guru secara lisan, dalam hal ini guru memang harus sebagai sosok yang memiliki kemampuan penguasaan materi yang tinggi, sebab jika tidak maka ia akan selalu kehabisan bahan untuk ceramahnya.

Strategi pembelajaran ceramah juga mempunyai keunggulan. Keunggulan strategi ini menurut Syaiful Bachri Djamarah, 2009, sebagai berikut:

a. dapat memperoleh sambutan kelas yang aktif;

b. Siswa mendapatkan kesempatan untuk mempertanyakan hal-hal yang kurang jelas atau yang belum dimengerti, dan pendidik akan langsung untuk menjawab pertanyaan tersebut

c. Memahami perbedaan pendapat antara guru dan siswa, dan dapat menjadikan dan membawanya sebagai bahan untuk diskusi.

Beberapa kelemahannya sebagai berikut:

a. Dalam prosesnya jalannya pembelajaran tidak lancar, sebab di iringi dengan kegiatan Tanya jawab

b. Jawaban yang dikemukakan siswa pada saat sesi tanya jawab tidak selalu benar, bahkan lebih banyak yang salah atau tidak sesuai dengan pembahasan

c. Karena pembelajaran hanya berupa penyampaian, maka terkadang banyak materi yang ditanyakan kepada siswa tidak dapat langsung dijawab, akan tetapi membuthkan waktu yang lama

d. Banyak pertanyaan yang terkadang menyimpang dari persoalan yang sedang dibahas, hal ini dikarenakan saat mendengarkan ceramah pendengar lebih tertarik dengan satu materi yang di luar dari pembahasan. (Tambak: 2014)

\section{Belajar dan Hasil Belajar}

Problematika pembelajaran, tidaklah dapat dilepaskan dari interaksi antara siswa dengan lingkungan belajarnya dan juga dengan pengajar. Proses pencapaian hasil belajar bukan hanya berasal dari guru saja, tetapi melibatkan banyak kegiatan dan tindakan yang kompleks dan luas, hal itu dikarenakan menyangkut dengan akal dan pikiran. Untuk terciptalah hasil belajar yang baik, maka manusia harus senantiasa mempergunakan akal pikiranya, mau belajar, mau untuk di bina, dilatih ataupun di ajar. Jika hal itu terdapat pada sikap manusia tentu pergantian hari demi hari akan selalu bermanfaat untuk peningkatan kualitas hasil belajarnya, setiap hari selalu ia akan memperbaharui keilmuannya. Orang yang 
meningkat kualitas hasil belajarnya tentu meningkat kualitas kehidupannya, bahkan mungkin saja peningkatan itu menjadi modal peningkatan untuk di akhirat.

Belajar merupakan perilaku yang dialami oleh setiap individu, ia tercipta akibat interaksi manusia dengan lingkugannya. Dari situ semua alat indranya berfungsi untuk mengumpulkan data dan informasi lanta direspon oleh otak untuk dinterpretasikan dengan kata-kata ataupun tindakan. Dan saat itulah seseorang dikatakan sedang mengalami proses belajar. Dalam perjalana kehidupan seseoarang dapat belajar dari mulai usia kecil hingga ia dewasa, bahkan banyak orang yang meyakini bahwa proses belajar terjadi sepanjang hayat manusia.

Pendapat Gagne, sebagaimana dirujuk oleh Dimyati dan Mudjiono (2011), belajar dapat dimaknai dengan suatu proses dimana seorang individu mengalami perubahan perilaku akibat pengalaman yang didapatkannya. Walker sebagaimana dikutip Winkel (2008) juga menguraikan bahwa belajar merupakan perubahan dalam hal penyelesaian tugas yang tercipta sebagai hasil dari interaksi individu terhadap pengalaman dan bukan termasuk dalam kategori kematangan rohaniah, cirinya seseorang belajar pertambahan itu berlangsung secara aktif, konsttan, serta berbekas. Sementara Piaget mengemukakan pendapat yang berkaitan dengan belajar, yakni seseorang yang memilki pengetahuan, sebenarnya pengetahuannya berasal dari interaksi secara kontiniu yang dilakukan manusia terhadap lingkungan. Perubahan tersebut membuat intlektual manusia semakin berkembang hari demi hari.

Beberapa pandangan tokoh terkait belajar di atas hanya termasuk sebagian kecil tentang pandangan yang ada. Namun yang pasti dapat disimpulkan bahwa belajar menyangkut beberapa hal: 1) interaksi individu dengan lingkungan belajar, 2) terdapat unsur kesengajaan manusia, 3) terjadi perubahan secara konstan, konitinu, dan terukur, 3) perubahan tersebut menambah pengetahuan setiap individu yang mengalaminya.

Kemudian jika dihubungkan dengan hasil belajar, jadi hasil belajar itu ialah kompetensi yang ada pada diri siswa sesudah ia memperoleh pengalaman belajar. Untuk mengukur pencapaian hasil belajar ini maka Benjamin S. Bloom sebagaimana yang dikutip oleh Ahmadi bahwa terdapat tiga ranah atau tiga domain sebagai basis untuk mengukur pencapaian hasil belajar siswa, yaitu domain kognitif, afektif dan psikomotorik. Dalam kontes penilaian hasil belajar siswa, maka sebenarnya ketika siswa berinteraksi dengan lingkunga belajar maka ketiga hal itulah yangakan menjadi tolak ukurnya. Siswa akan dinilai apakah ia mampu untuk memahami materi pelajarn yang disampaikan? apakah ia mampu untuk 
menghayati materi tersebut? Dan yang terakhir apakah ia mampu untuk terampil dalam melakukannya dalam kehidupan sehari-hari?. Jika hanya salah satu saja atau ada salah satu yang tak dikuasi oleh siswa, maka tentu saja pencapaian hasil belajarnya tidaklah dapat dikakatan secara totalitas tercapai secara penuh. Tentu ia dikatakan berhasil di satu sisi, dan dikatakan gagal di sisi yang lain.

Khusus untuk hasil belajar pada ranah kognitif, ia berkaitan dengan pengetahuan (otak) menurut Hamzah B.Uno (2009) semua hal yang terkait dengan aktivitas otak, maka dikategorikan ke dalam ranah kognitif. Pada domain kognitif terdapat enam tingkatan berfikir mulai dari level yang paling rendah sampai pada level yang paling tinggi. Adapun enam level itu ialah sebagai berikut: Djiwandono, 2008)

a. Pengetahuan, level ini sebatas pada ingatan akan hal-hal yang telah dipelajari, sehingga dapat dengan mudah digali atau diingat saat dibutuhkan

b. Pemahaman, level ini meliputi kemampuan dalam menangkap makna dari materi pelajaran, ia tidak sekedar mengetahui akan tetapi sampai pada memahami

c. Penerapan, meliputi kemampuan untuk menerapkan konsep atau teori dalam memecahkan atau menjawab satu persoalan nyata dalam kehidupan siswa

d. Analisis, pada level ini siswa mampu untuk mengerahkan pemikirannya untuk memilah milih bahan kedalam bagian atau menyusun suatu konsep atau teori yang kompleks menjadi terstruktur, terorganisasi, dan sederhana untuk dipahami.

e. Sintesis, level ini siswa mampu untuk saling menghubungkan satu sama lain yang terpisah untuk menjadi satu kesatuan.

f. Evaluasi, level ini siswa mampu untuk mempertimbangkan dan memberikan penilaian terhadap pengetahuan yang telah didapatnya dengan dasar indicator atau kriteria yang telah ditentukan.

Secara global terdapat dua hal yang dapat mempengaruhi hasil belajar seseorang, yakni faktor yang berasal dari dalam dan luar diri seseoang. Adapun faktor dari dalam terbagi menjadi dua bagian yakni:

a. Kondisi fisik, kondisi fisik baik dalam keadaan sehat maupun sakit kedua-keduanya memberikan pengaruh terhadap hasil belajar seseorang, tentu hasil belajar akan jauh lebih baik saat seseorang tersebut dalam keadaan sehat.

b. Kondisi mental atau psikis, psikis mausia tentu yang paling banyak memberikan pengaruh seperti minat, 
bakat, emosi, motivasi, intlegensi dan sebagainya

Sedangkan faktor dari luar diri seseorang dapat diklasifikasikan sebagai berikut:

a. Kondisi alam, seperti iklim, sirkulasi ruangan, sehingga dalam hal ini dibutuhkan pengelolan ruang kelas yang baik

b. Kondisi sosial, seperti latar belakang kehidupan sosial seseorang, lingkungan sosial tempat tinggal seseorang.

c. Sarana dan prasarana, semakin lengkap dan mendukung sarana dan prasarana yang ada maka akan semakin mendukng tercapainya hasil belajar yang baik. (Pingge \& Wangid: 2015).

Lain halnya dengan Sudjana (2008) yang mengemukakan bahwa hasil belajar dipengaruhi oleh mutu dari pembelajaran itu sendiri, dalam hal ini menyangkut tiga hal yakni kompetensi guru, karateristik kelas, dan karekteristik sekolah. Kompetensi guru tentu berkaitan dengan kemampuan guru dalam mengelola pembelajaran dengan baik, mulai dari merencanakan pembelajran, mengorganisasikan strategi dan media pembelajaran, dan mengevaluasi pembelajaran. Selain itu juga kompetensi kepribadian sehingga guru dapat menjadi sosok yang berwibawa, dan dianggap sebagai leader dalam penentuan arah pebelajaran.
Karekteristik kelas berkaitan dengan pengelolaan kelas yang dapat mendukung siswa agar nyaman dan tenang selama proses pembelajaran. Sedangkan karekteristik sekolah berkaitan dengan fasilitas yang tersedia di sekolah untuk menunjang tercapainya tujuan pembelajaran, mulai dari perpustakaan sekolah, laboratorium, serta fasilitas sekolah lain yang relevan dengan kemajuan hasil belajar siswa. Tentu semakin hari bukan hanya kompetensi siswa saja yang menjadi faktor utama perhatian, akan tetapi faktor komptensi guru, kelas, dan sarana dan prasarana sekolah juga turut menjadi perhatian serius demi tercapainya hasil belajar sebagaimana yang diingingkan.

Penelitian khusus berkenaan dengan hasil belajar siswa kelas 7 MTS Bina Taruna pada pelajaran Pendidikan Agama Islam dengan materi zakat fitrah dan zakat mal.

\section{Materi Zakat}

Segi bahasa zakat artinya tumbuh, suci, berkah, dan berkembang. Sedangkan segi istilah zakat berarti mengeluarkan hak orang lain (yang mustahak) yang terdapat pada kita berbentuk panganan pokok yang ada di suatu Negara atau dapat juga berbentuk harta.

Dalam islam zakat terbagi kepada dua yakni zakat fitrah dan zakat mal. Zakat fitrah ialah zakat berbentuk panganan pokok disuatu Negara, yang ditunaikan sesudah melaksanakan puasa selama satu bulan di ramadhan, penunaiannya dilakukan di akhir 
ramadhan sampai menjelang shalat idul fitri.

Dalam fikih hukumnya wajib bagi tiap individu. Hal ini sebagaimana dijelaskan melalui sabda Nabi Saw: Dari Abu Sai'd ia berkata, Kami mengeluarkan rakat fitrah satu sa', dari makanan, gandum, kurma, susu kering, atau anggur kering”. (H.R. Bukhori Muslim).

Syarat wajib zakat fitrah di antaranya beragama Islam, lahir sebelum tenggelam matahari pada hari akhir bulan ramadhan, terdapat harta yang lebih hendak dibayarkan, dan terdapat juga harta untuk bagian keluarga yang dinafkahi. Adapun waktu pembayaran zakat fitrah mulai dari datangnya bulan suci ramadhan (awal ramdhan), hingga sebelum melaksanakan shalat idul fitri. Sedangkan waktu untuk mendistribusikannya kepada yang berhak menerimanya sebaiknya sebelum melaksanakan shalat Ied.

\section{1) Zakat maal}

Zakat maal artinya zakat harta, maksudnya membersihakan harta yang dimiliki kepada mustahiq (yang berhak). Hukumnya fardu 'ain. Perintah mengeluarkan zakat mal sama halnya dengan perintah zakat fitrah. Zakat termasuk ibadah yang memiliki nilai istimewa dalam Islam, hal ini terlihat dari beberapa penjelasan yang terdapat di dalam Alquran, bahkan keistimewaanya selalu disandingkan dengan ibadah yang istimewa yakni shalat.

\section{METODE PENELITIAN}

Metode yang dipergunakan dalam melakukan penelitian ini yaitu penelitian Eksperimen, dengan model pengendalian dan pengontrolan terhadap suatu objek yang mampu menunjukkan adanya keterkaitan sebab dan akibat antara variabel dependen dengan variabel independen.

Jumlah sampel diperoleh dari data seluruh siswa kelas VII MTs Bina Taruna Marelan tahun pembelajaran 2015/2016 berjumlah 60 siswa tersebar atas dua kelas paralel sebagaimana tertera pada tabe di bawah ini:

Tabel 1. Sampel Penelitian

\begin{tabular}{|l|l|l|}
\hline No. & Kelas & Jumlah Populasi \\
\hline 1. & VII.1 & 30 siswa \\
\hline 2. & VII.2 & 30 siswa \\
\hline \multicolumn{2}{|c|}{ Total } & 60 siswa \\
\hline
\end{tabular}

Variabel dalam penelitian ini ialah:

1. Variabel bebas $1\left(\mathrm{X}_{1}\right)$ yakni hasil Belajar Pendidian Agama Islam yang menggunakan Strategi pembelajaran Active Knowledge Sharing.

2. Variabel bebas $2\left(\mathrm{X}_{2}\right)$ yakni hasil belajar Pendidikan Agama Islam Menggunakan Strategi Pembelajaran ceramah.

Desain penelitian yang digunakan adalah desain group post test, pelaksanaannya digambarkan Sugiyono sebagaimana tertera pada tabel berikut:

Tabel 2. Disain Group

\begin{tabular}{|l|c|c|}
\hline \multicolumn{1}{|c|}{ Kelas } & Perlakuan & Posttest \\
\hline Eksperimen & $\mathrm{X}_{1}$ & $\mathrm{~T}_{1}$ \\
\hline Kontrol & $\mathrm{X}_{2}$ & $\mathrm{~T}_{2}$ \\
\hline
\end{tabular}


Keterangan:

T1 : Tes akhir menggunakan strategi pembelajaran active knowledge sharing

T2 : Tes akhir menggunakan strategi pembelajaran ceramah

X1 : Perlakuan menggunakan strategi pembelajaran active knowledge sharing

X2 : Perlakuan menggunakan strategi pembelajaran ceramah

Instrumen penelitan merupakan alat yang dipergunakan untuk mengumpukan data penelitian. Suharsimi Arikunto menjelaskan bahwa instrument penelitian termasuk alat untuk menjaring data dan informasi penelitian. Instrumen itu sebagai alat penjaring bagi peneliti, untuk mendapatkan data sesuai dengan yang diinginkan. Mutu dari satu instrument menentukan mutu dari data yang diperoleh. Instrumen yang dipilih untuk mendapatkan data penelitian ialah Tes. Tes tersebut yakni tes untuk mengukur hasil belajar Pendidikan Agama Islam berbentuk Objektif Tes, terdiri atas 20 pertanyaan. Setiap pertanyaan mempunyai 4 (empat) gradasi jawaban yakni a, b, c, d. Tes itu diujkan kepada peserta didik setelah selesai mendapatan perlakuan pembelajaran menggunakan strategi active knowledge sharing dan ceramah. Setiap jawaban peserta didik yang benar akan diberikan skor 20 per butir soal.

Analisis data merupakan kegiatan untuk mengolah data temuan penelitian, untuk menjawab semua pertanyaan penelitian. Menurut Sudijono (2008) kegiatan analis data secara sederhana berkenaan dengan mengolah informasi temuan penelitian. Di dalamnya terdapat kegiatan menyusun, mengoragnisasikan data, menyusun data pada tabel menurut kategorinya, membuat diagram atau grafik. Hal itu semua bertujuan untuk lebih memudahkan peneliti dalam menyajikan temuan penelitian dan memudahkan pembaca untuk memahami temuan penelitian.

Sebagaimana tujuan penelitian yang ada, maka analisis penelitian yang digunakan ialah analis deskriptif, data yang diperoleh dari siswa kemudian disajikan dalam bentuk deksripsi atau uraian terperinci. Pelacakan data hasil belajar yang telah dilakukan oleh peneliti dalam bentuk penyebaran tes hasil belajar PAI, terlebih dahulu akan dikoreksi jawabannya. Setelah di peroleh data tersebut, maka selanjutnya diolah untuk menetukan simpulan yang dan untuk memvalidasi kebenaran hipotesis penelitian. Pengolahan data dilakukan dengan mengunakan uji statisik dua pihak dengan mengkomparasikan Harga kritik $\mathrm{t}$ hitung dengan $t$ tabell, dengan batas taraf signifikansi $5 \%$ dan batas taraf kepercayaan $95 \%$. Namun sebelumnya terlebih dahulu dilakukan uji t-tes dengan langkah sebagai berikut: 
1. Mentabulasi perolehan skor kelas eksperimen (X1)

2. Mentabulasi perolehan skor kelas kontrol (X2)

3. Menentukan Mean variabel X1 dan $\mathrm{X} 2$ dengan penggunan rumus:

$$
\bar{X}=\frac{\sum X}{N}
$$

Keterangan:

M : rata-rata (mean)

$\sum \mathrm{X} \quad$ : total jumlah frekuensi

$\mathrm{N} \quad$ : total jumlah sampel

4. Menentukan standar deviasi variabel $\mathrm{X} 1$ dan X2, dengan penggunaan rumus:

$$
S D=\sqrt{\frac{N X \sum X^{2}-\left(\sum X\right)^{2}}{N(N-1)}}
$$

Keterangan:

SD : standar deviasi

$\sum \mathrm{X} 2$ : jumlah kuadrat nilai frekuensi

$\mathrm{N} \quad$ : jumlah sampel

5. Melakukan uji persyaratan analisis data:

a. Uji Normalitas data

Uji normalitas data dengan menggunakan uji Lilliefors dengan langkahlangkah sebagai berikut:

1) Pengamatan $X 1, X 2, X 3 \ldots, X n$ dijadikan bentuk baku Z1, Z2, Z3..., Zn dengan menggunakan rumus:

$$
Z_{1}=\frac{X i-\bar{X}}{S}
$$

Keterangan:

$\mathrm{Xi}=$ Batas kelas

$\bar{X} \quad=$ Rata-rata

$\mathrm{S} \quad=$ Standar deviasi

Yang masing-masing dihitung dengan rumus:

$$
\begin{aligned}
& \bar{X}=\frac{\sum X}{n} \\
& S=\sqrt{\frac{n \sum X^{2}-\left(\sum X^{2}\right)}{n(n-1)}}
\end{aligned}
$$

Untuk tiap angka baku dihitung peluangnya dengan $\mathrm{F}(\mathrm{Z} 1)=\mathrm{P}(\mathrm{Z} \leq \mathrm{Zi})$ dengan menggunakan distribusi normal.

2) Menghitung peluang $F(Z 1)=P(Z \leq$ Z) dengan menggunakan daftar distribusi normal baku.

3) Selanjutnya menghitung proporsi dinyatakan dengan Szi dengan rumus:

$\mathrm{S}\left(\mathrm{Z}_{\mathrm{i}}\right)=\frac{\mathrm{Z}_{1}, \mathrm{Z}_{2, \ldots} \mathrm{Z}_{3, \ldots \ldots \ldots . . .} \mathrm{Z}_{\mathrm{n}} \text { yang diambil } \leq \mathrm{Z}_{1}}{\mathrm{n}}$ 4) Menghitung selisih ${ }^{\mathrm{n}} \mathrm{F}(\mathrm{Zi})$ dengan $\mathrm{S}(\mathrm{Zi})$ dan menetapkan harga mutlaknya.

5) Mengambil harga Lo yaitu harga paling besar di antara harga mutlak. Kriteria: terima hipotesis jika harga Lo $<$ nilai kritik $<$ untuk liliefors dengan taraf nyata $\alpha=0,05$ dalam hal lain ditolak.

b. Uji Homogenitas

Jika dalam pengujian normalitas dan yang berdistribusi normal, maka dilanjutkan 
dengan uji homogenitas yaitu menguji kesamaan varian menggunakan rumus:

$$
\begin{aligned}
& \mathrm{F}=\frac{\text { Varians terbesar }}{\text { Varians terkecil }} \\
& \mathrm{F}=\frac{\mathrm{S}_{1}^{2}}{\mathrm{~S}_{2}^{2}}
\end{aligned}
$$

Keterangan:

$\mathrm{S}^{2}{ }_{1}=$ Varians dari kelompok besar.

$\mathrm{S}_{2}^{2}=$ Varians dari kelompok kecil.

Kriteria pengujian adalah: terima Ho jika $\mathrm{F}_{\text {hitung }}<\mathrm{F}_{\text {tabel }}$.

\section{Pengujian Hipotesis}

Hipotesis diuji menggunakan uji beda rata-rata dua sampel berhubungan (berpasangan) dengan rumus yang dikemukakan Sugiyono:

Keterangan:

$$
t_{\text {hitung }}=\frac{\bar{X}_{1}-\bar{X}_{2}}{\sqrt{\frac{s_{1}{ }^{2}}{n_{1}}+\frac{s_{2^{2}}}{n_{2}}}}
$$

$\mathrm{t}=$ harga $\mathrm{t}$ hasil perhitungan

$\mathrm{X}_{1}=$ Rata-rata skor kelas eksperimen

$\mathrm{X}_{2}=$ rata - rata skor kelas kontrol

$\mathrm{n} 1=$ jumlah data eksperimen

$\mathrm{n} 2=$ jumlah data kontrol

S12 = varians pada kelas eksperimen

S22 = varians pada kelas kontrol

Setelah harga $t_{\text {hitung }}$ didapatkan, kemudian dikonsultasikan dengan tabel distribusi $t$. pada taraf signifikansi $\alpha=0,05$. Jika $t_{\text {hitung }}>$ $\mathrm{t}_{\text {tabel }}$ maka Ha diterima.

\section{HASIL DAN PEMBAHASAN}

Setelah data diperoleh maka berikutnya melakukan penganalisisan data.
Di bawah ini akan dipaparkan data dari masing-masing baik kelas control ataupun eksperimen. Data yang dimaksud di sini ialah hasil belajar PAI materi zakat fitrah dan zakat mal.

\section{Hasil belajar PAI menggunakan}

strategi Active Knowledge Sharing

\section{Siswa kelas VII MTS Bina Taruna}

\section{Marelan.}

Setelah dilakukan pembelajaran dengan strategi AKS, maka Skor hasil belajar sebagaimana berikut ini.

\begin{tabular}{|c|c|c|c|c|}
\hline No & Nama Siswa & Skor & $\begin{array}{c}\text { Nilai } \\
\left(\mathrm{X}_{1}\right)\end{array}$ & $\mathbf{X}_{1}^{2}$ \\
\hline 1 & A. Partogi Tumanggor & 16 & 80 & 640 \\
\hline 2 & Agung Firmansyah & 17 & 85 & 722 \\
\hline 3 & Andrean Syahputra & 13 & 65 & 422 \\
\hline 4 & Andria Prayuda & 13 & 65 & 422 \\
\hline 5 & Arya Fahreza & 14 & 70 & 490 \\
\hline 6 & Bayu Kurniawan & 14 & 70 & 490 \\
\hline 7 & Dandi Prijanto & 14 & 70 & 490 \\
\hline 8 & Eggi Risdianto & 12 & 60 & 360 \\
\hline 9 & Faisal Yahya Nasution & 15 & 75 & 562 \\
\hline 10 & Fajar Simbolon & 13 & 65 & 422 \\
\hline 11 & Feri Zaldi & 15 & 75 & 562 \\
\hline 12 & Ikwan Muzakir & 15 & 75 & 562 \\
\hline 13 & Irwansyah & 16 & 80 & 640 \\
\hline 14 & Jalaluddin Pohan & 15 & 75 & 562 \\
\hline 15 & Jeri Andi Chandra & 16 & 80 & 640 \\
\hline 16 & Jeri Waluyo Dinata & 13 & 65 & 422 \\
\hline 17 & M. Aidil Dasari & 13 & 65 & 422 \\
\hline 18 & M. Aldiansyah & 15 & 75 & 562 \\
\hline 19 & M. Fadlan & 16 & 80 & 640 \\
\hline 20 & M. Ismail & 14 & 70 & 490 \\
\hline 21 & M. Noval & 14 & 70 & 490 \\
\hline 22 & Peri Sandria & 16 & 80 & 640 \\
\hline 23 & Rahmat Rizki & 16 & 80 & 640 \\
\hline 24 & Reza Fahlevi & 13 & 65 & 422 \\
\hline 25 & Rianto & 16 & 80 & 640 \\
\hline 26 & Rizki Saputra & 13 & 65 & 422 \\
\hline 27 & Romi Syahputra & 15 & 75 & 562 \\
\hline
\end{tabular}

Tabel 3. Hasil Belajar PAI Menggunakan

Strategi Active Knowledge Sharing 


\begin{tabular}{|c|l|c|c|c|}
\hline 28 & Roni Aksan Nasution & 16 & 80 & 640 \\
\hline 29 & Suhanda & 16 & 80 & 640 \\
\hline 30 & Swarmala & 17 & 85 & 722 \\
\hline & Jumlah & & $\mathbf{2 2 0 5}$ & $\mathbf{1 6 3}$ \\
\hline & Nilai Rata-rata & & $\mathbf{7 3 , 5 0}$ & \\
\hline
\end{tabular}

Berdasarkan tabel 3, hasil belajar Pendidikan Agama Islam menggunakan strategi active knowledge sharing diperoleh penyebaran skor 60 sampai 85 . Skor terendah 60 dan tertinggi 85. Nilai rata-rata yaitu jumlah nilai dibagi dengan jumlah siswa:

$$
\frac{2205}{30}=73,50
$$

Dengan begitu, skor hasil belajar PAI menggunakan strategi active knowledge sharing (kelompok eksperimen) dalam kategori B (baik). Selanjutnya perhitungan mean dan standar deviasi. Dari tabel 4.1 diperoleh data:

$\sum \mathrm{X} 1=2205 ; \sum \mathrm{X} 12=163475 ; \mathrm{N}=30$

maka mean:

$$
\begin{aligned}
\bar{X}_{1} & =\frac{\sum X_{1}}{N} \\
& =\frac{2205}{30} \\
& =73,50
\end{aligned}
$$

Standar Deviasinya:

$$
\begin{aligned}
S D & =\sqrt{\frac{N \sum X_{1}{ }^{2}-\left(\sum X_{1}\right)^{2}}{N(N-1)}} \\
& =\sqrt{\frac{(30)(163475)-(2205)^{2}}{30(30-1)}} \\
& =\sqrt{\frac{4904259-4862025}{870}} \\
& =\sqrt{\frac{42234}{870}} \\
& =\sqrt{48,54} \\
& =6,97
\end{aligned}
$$

Disimpulkan, nilai rata-rata hasil belajar Pendidikan Agama Islam menggunakan strategi active knowledge sharing adalah 73,50 dan standar deviasinya 6,97 termasuk dalam kategori B (baik).

\section{Hasil Belajar PAI Menggunakan}

\begin{tabular}{|c|c|c|c|c|}
\hline No & Nama Siswa & Skor & $\left(\mathrm{X}_{2}\right)$ & $\mathbf{X}_{2^{2}}^{2}$ \\
\hline 1 & Ahmad Kholik & 12 & 60 & 3600 \\
\hline 2 & Aidil Akbar & 10 & 50 & 2500 \\
\hline 3 & Akbar Rafsanjani & 11 & 55 & 3025 \\
\hline 4 & Angga Kurniawan & 12 & 60 & 3600 \\
\hline 5 & Ardiansyah & 11 & 55 & 3025 \\
\hline 6 & Budi Kurniawan Lbs & 13 & 65 & 4225 \\
\hline 7 & Charles & 14 & 70 & 4900 \\
\hline 8 & Dedi Hartono & 9 & 45 & 2025 \\
\hline 9 & Deni Wahyudi & 15 & 75 & 5625 \\
\hline 10 & Eko Pranoto & 10 & 50 & 2500 \\
\hline 11 & Erik Alaskah & 12 & 60 & 3600 \\
\hline 12 & Erik Pohan & 13 & 65 & 4225 \\
\hline 13 & Fuad Fadillah Nast & 8 & 40 & 1600 \\
\hline 14 & Januar Iskandar & 15 & 75 & 5625 \\
\hline 15 & Josua & 16 & 80 & 6400 \\
\hline 16 & Julham & 13 & 65 & 4225 \\
\hline 17 & M. Riki Wirdiansyah & 12 & 60 & 3600 \\
\hline 18 & M. Toni Atmajaya Srg & 11 & 55 & 3025 \\
\hline 19 & Mahmud Aziz Hsb & 10 & 50 & 2500 \\
\hline 20 & Mujianto & 13 & 65 & 4225 \\
\hline 21 & Niko Zakariah Baroka & 15 & 75 & 5625 \\
\hline 22 & Putra Andika & 14 & 70 & 4900 \\
\hline 23 & Rahmat Fauzi & 10 & 50 & 2500 \\
\hline 24 & Rahmat Hidayat & 13 & 65 & 4225 \\
\hline 25 & Ramli Saputra & 12 & 60 & 3600 \\
\hline 26 & Ridho Filliali Akyar & 16 & 80 & 6400 \\
\hline 27 & Roky Reza & 15 & 75 & 5625 \\
\hline 28 & Wijaya & 15 & 75 & 5625 \\
\hline 29 & Yogi Ardiansyah & 13 & 65 & 4225 \\
\hline \multirow[t]{3}{*}{30} & Zulhamsyah Wahyu P & 14 & 70 & 4900 \\
\hline & Jumlah & & 1885 & 121675 \\
\hline & Rata-rata & & 62,83 & \\
\hline
\end{tabular}

Strategi Ceramah Siswa Kelas VII

\section{MTs Bina Taruna Marelan}

Setelah kelompok kontrol melaksanakan pembelajaran Pendidikan Agama Islam menggunakan strategi pembelajaran ceramah, maka skor nilai siswa sebagaimana tertera di bawah ini:

Tabel 4. Hasil Belajar Pendidikan Agama Islam Menggunakan Strategi Ceramah 
Berdasarkan tabel 4 di atas, diperoleh penyebaran nilai 40 sampai 85 . Nilai minimu 40 dan maksimum 85. Nilai rerata hasil belajar Pendidikan Agama Islam menggunakan strategi pembelajaran ceramah (kelompok kontrol) yaitu jumlah nilai dibagi dengan jumlah siswa, sebagai berikut:

$$
\frac{1885}{30}=62,83
$$

Dengan demikian hasil belajar Pendidikan Agama Islam menggunakan strategi pembelajaran cerama (kelompok kontrol) dalam kategori C (cukup).

Selanjutnya perhitungan mean dan standar deviasi yaitu :

$\sum \mathrm{X} 2=1885 ; \sum \mathrm{X} 22=121675 ; \mathrm{N}=30$

maka mean:

$$
\begin{aligned}
\bar{X}_{2} & =\frac{\sum X_{2}}{N} \\
& =\frac{1885}{30} \\
& =62,83
\end{aligned}
$$

Standar Deviasinya:

$$
\begin{aligned}
S D & =\sqrt{\frac{N \sum X_{2}^{2}-\left(\sum X_{2}\right)^{2}}{N(N-1)}} \\
& =\sqrt{\frac{(30)(121675)-(1885)^{2}}{30(30-1)}} \\
& =\sqrt{\frac{3650250-3553225}{870}} \\
& =\sqrt{\frac{97025}{870}} \\
& =\sqrt{111,52} \\
& =10,56
\end{aligned}
$$

Disimpulkan, nilai rata-rata hasil belajar Pendidikan Agama Islam menggunakan strategi pebelajaran ceramah adalah 62,83 dan standar deviasinya 10,56 termasuk dalam kategori C (cukup).

\section{Efektivitas Strategi Pembelajaran}

Active Knowledge Sharing terhadap

Hasil Belajar PAI Siswa Kelas VII

\section{MTs Bina Taruna Marelan}

Berdasarkan data di atas, disimpulkan bahwa hasil belajar Pendidikan Agama Islam siswa kelas VII MTs Bina Taruna Marelan sebagai berikut:

Tabel 4. Data Hasil Belajar PAI

\begin{tabular}{|c|c|c|c|}
\hline Kelas & N & $\begin{array}{c}\text { Nilai } \\
\text { Rata-rata }\end{array}$ & $\begin{array}{c}\text { Standar } \\
\text { Deviasi }\end{array}$ \\
\hline Eksperimen & 30 & 73,50 & 6,97 \\
Kontrol & 30 & 62,83 & 10,56 \\
\hline
\end{tabular}

Berdasarkan tabel 4 di atas, menunjukkan komparasi skor hasil belajar PAI siswa menggunakan strategi active knowledge sharing dengan ceraah, adalah:

$\%$ efektivitas $=\frac{\bar{X}_{1}-\bar{X}_{2}}{\bar{X}_{2}}$

$\%$ efektivitas $=\frac{73,50-62,83}{62,83} \times 100 \%$

$\%$ efektivitas $=16,98 \%$

Dapat dikatakan strategi pembelajaran active knowledge sharing lebih efektif sebesar $16,98 \%$ dari strategi pembelajaran ceramah dalam meningkatkan hasil belajar Pendidikan Agama Islam siswa kelas VII MTs Bina Taruna Marelan tahun pembelajaran 2015/2016. 


\section{a. Uji Persyaratan Analisis Data}

Persyaratan analisis ini digunakan untuk mengetahui apakah sampel yang diteliti berasal dari populasi yang berdistribusi normal dan variansi dari kelompok yang membentuk sampel adalah homogen.

\section{1) Uji Normalitas Data Kelompok Ekperimen}

Tabel 5. Uji Normalitas Kelompok Eksperimen

\begin{tabular}{|c|c|c|c|c|c|c|c|}
\hline $\mathbf{X}$ & $\mathbf{F}$ & $\mathbf{F}_{\text {kum }}$ & $\mathbf{Z i}$ & $\mathbf{F}_{\text {tab }}$ & $\mathbf{F}(\mathbf{Z i})$ & $\mathbf{S}(\mathbf{Z i})$ & $\begin{array}{c}\mathbf{L}_{\mathbf{o}}= \\
\mathbf{F}(\mathbf{Z i})- \\
\mathbf{S}(\mathbf{Z i})\end{array}$ \\
\hline 60 & 1 & 1 & - & - & 0.0262 & 0.0333 & 0.0071 \\
\hline 65 & 7 & 8 & - & - & 0.2112 & 0.2667 & 0.0555 \\
\hline 70 & 5 & 13 & - & - & 0.3085 & 0.4333 & $\mathbf{0 . 1 2 4 8}$ \\
\hline 75 & 6 & 19 & 0.22 & 0.1915 & & & \\
\hline 80 & 9 & 28 & 0.93 & 0.3238 & 0.8238 & 0.9333 & 0.1095 \\
\hline 85 & 2 & 30 & 1.65 & 0.4505 & 0.9505 & 1 & 0.0495 \\
\hline
\end{tabular}

Berdasarkan tabel 5, harga yang paling besar di antara harga-harga mutlak selisih tersebut adalah $L_{0}=0,1248$ dengan $\mathrm{n}=30$ dan taraf nyata $\alpha=0,05$ didapat Ltab $=0,161$ yang lebih besar dari Lo $=0,1248($ Lo $<$ Ltabel $=$ $0.1248<0.161)$ sehingga hipotesis nol diterima. Dapat disimpulkan bahwa data kelompok eksperimen berdistribusi normal.

\section{2) Uji Normalitas Kelas Kontrol}

Untuk skor hasil uji normalitas dapat di bawah ini:

Tabel 6.Uji Normalitas Kelompok Kontrol

\begin{tabular}{|c|c|c|c|c|c|c|c|}
\hline $\mathbf{X}$ & $\mathbf{F}$ & $\mathbf{F}_{\text {kum }}$ & $\mathbf{Z i}$ & $\mathbf{F}_{\text {tab }}$ & $\mathbf{F}(\mathbf{Z i})$ & $\mathbf{S}(\mathbf{Z i})$ & $\begin{array}{c}\mathbf{L}_{\mathbf{o}}=\mathbf{F}(\mathbf{Z i})- \\
\mathbf{S}(\mathbf{Z i})\end{array}$ \\
\hline 40 & 1 & 1 & -2.16 & -0.4846 & 0.0154 & 0.0333 & 0.0179 \\
\hline 45 & 1 & 2 & -1.69 & -0.4545 & 0.0455 & 0.0667 & 0.0212 \\
\hline 50 & 4 & 6 & -1.21 & -0.3869 & 0.1131 & 0.2000 & $\mathbf{0 . 0 8 6 9}$ \\
\hline 55 & 3 & 9 & -0.74 & -0.2704 & 0.2296 & 0.3000 & 0.0704 \\
\hline 60 & 5 & 14 & -0.27 & -0.1064 & 0.3936 & 0.4667 & 0.0731 \\
\hline 65 & 6 & 20 & 0.21 & 0.0832 & 0.5832 & 0.6667 & 0.0835 \\
\hline 70 & 3 & 23 & 0.68 & 0.2517 & 0.7517 & 0.7667 & 0.0150 \\
\hline 75 & 5 & 28 & 1.15 & 0.3749 & 0.8749 & 0.9333 & 0.0584 \\
\hline 80 & 2 & 30 & 1.63 & 0.4484 & 0.9484 & 1 & 0.0516 \\
\hline
\end{tabular}

Berdasarkan tabel 6, harga yang paling besar di antara harga-harga mutlak selisih tersebut adalah Lo $=0,0869$ dengan $n$ $=30$ dan taraf nyata $\alpha=0,05$ didapat Ltab $=0,161$ yang lebih besar dari Lo $=0,0869$ $($ Lo $<$ Ltabel $=0.0869<0.161)$ sehingga hipotesis nol diterima. Dapat disimpulkan bahwa data kelompok kontrol berdistribusi normal.

\section{3) Uji Homogenitas Data}

Uji ini dilaksanakan untuk mengukur sampel yang digunakan dalam penelitian ini homogeny atau tidak, dan apakah sampel yang dipakai dalam penelitian ini dapat mewakili seluruh populasi yang ada. Perhitungannya sebagai berikut:

Dari data diperoleh:

$$
\begin{aligned}
& \bar{X}_{1}=73,50 ; \mathrm{SD}=6,97 ; \mathrm{SD} 2=48,58 ; \mathrm{N}=30 \\
& \bar{X}_{2}=62,83 ; \mathrm{SD}=10,56 ; \mathrm{SD} 2=111,51 ; \mathrm{N}=30
\end{aligned}
$$

Maka harga $\mathrm{F}_{\text {hitung }}$ dibandingkan $\mathrm{F}_{\text {tabel }}$ diperoleh $\mathrm{F}_{\text {hitung }}<\mathrm{F}_{\text {tabel }}$ atau 2,295 3,316, berarti sampel yang diteliti dala penelitian ini berasal dari kelompok yang homogen. Artinya, data yang diperoleh dapat mewakili seluruh populasi.

\section{4) Pengujian Hipotesis}

Setelah dicari normalitas dan homogenitas dari kelompok eksperimen (X1) dan kelompok kontrol (X2), maka hasilnya menunjukkan bahwa persyaratan analisis dalam penelitian ini berdistribusi normal dan bervarians kelompok-kelompok sampel adalah homogen. Hal ini 
menunjukkan bahwa persyaratan analisis dalam penelitian ini telah terpenuhi, sehingga dapat dilanjutkan pada pengujian lebih lanjut yaitu pengujian hipotesis dengan uji " $\mathrm{t}$ ".

Pengujian hipotesis bertujuan untuk mengetahui apakah strategi active knowledge sharing efektif digunakan dalam meningkatkan hasil belajar Pendidikan Agama Islam pada siswa kelas VII MTs Bina Taruna Marelan tahun pembelajaran 2015/2016.

Berdasarkan data penelitian, diperoleh skor masing-masing seperti tertera di bawah ini:

$$
\begin{aligned}
& \bar{X}_{1}=73,50 ; \mathrm{SD}=6,97 ; \mathrm{SD} 2=48,58 ; \mathrm{N}=30 \\
& \bar{X}_{2}=62,83 ; \mathrm{SD}=10,56 ; \mathrm{SD} 2=111,51 ; \mathrm{N}=30
\end{aligned}
$$

dengan menggunakan rumus, maka seluruh skor di atas dimasukkan ke dalam rumus dan diperoleh hasil perhitungannya seperti yang tertera berikut ini:

$$
\begin{aligned}
t_{\text {hitung }} & =\frac{\bar{X}_{1}-\bar{X}_{2}}{\sqrt{\frac{s_{1}^{2}}{n_{1}}+\frac{s_{2}^{2}}{n_{2}}}} \\
& =\frac{73,50-62,83}{\sqrt{\frac{48,58}{30}+\frac{111,51}{30}}} \\
& =\frac{10,67}{\sqrt{1,62+3,72}} \\
& =\frac{10,67}{\sqrt{5,34}} \\
& =\frac{10,67}{2,31} \\
& =4,619
\end{aligned}
$$

Dari daftar distribusi t untuk $\alpha=0,05$ dan $\mathrm{dk}=30+30-2=58$, diperoleh harga ttabel $=1,668$. Dengan membandingkan thitung dengan ttabel diperoleh thitung $>$ ttabel atau 4,619 > 1,668, sehingga $\mathrm{Ha}$ diterima dan Ho ditolak. Disimpulkan bahwa strategi pembelajaran active knowledge sharing efektif digunakan dalam meningkatkan hasil belajar Pendidikan Agama Islam siswa kelas VII MTs Bina Taruna Marelan tahun pembelajaran 2015/2016. Berdasarkan hal ini, maka hipotesis alternatif $(\mathrm{Ha})$ dinyatakan benar dan dapat diterima. Dengan diterimanya $\mathrm{Ha}$, maka Ho ditolak.

\section{SIMPULAN}

Dari analisa dan pembahasan yang dilakukan maka dapat disimpulkan bahwa: Hasil belajar Pendidikan Agama Islam menggunakan strategi pembelajaran active knowledge memperoleh nilai rata-rata 73,50 termasuk dalam kategori B (baik) dan hasil belajar Pendidikan Agama Islam menggunakan strategi pembelajaran ceramah memperoleh nilai rata-rata 62,83 termasuk dalam kategori C (cukup). Strategi pembelajaran active knowledge sharing lebih efektif sebesar $16,88 \%$ dari strategi pembelajaran ceramah. Hal ini disebabkan strategi pembelajaran active knowledge sharing merangsang berpikir tingkat tinggi dalam situasi berorientasi masalah sehingga dalam pelaksanaannya menyenangkan 


\section{DAFTAR PUSTAKA}

Ahmadi, A. 2004, Psikologi Belajar, Jakarta: Rineka Cipta.

Arikunto, S. 2010. Prosedur Penelitian suatu Pendekatan Prakti. Jakarta. Rineka Cipta.

Assingkily, Muhammad Shaleh \& Mikyal Hardiyati. 2019. "Analisis Perkembangan Sosial-Emosional Tercapai dan Tidak Tercapai Siswa Usia Dasar" Al-Aulad: Journal of Islamic Primary School, 2 (2): 19-31. http://journal.uinsgd.ac.id/index.php /al-aulad/article/view/5210/0.

Assingkily, Muhammad Shaleh \& Miswar. 2020. "Urgensitas Pendidikan Akhlak Bagi Anak Usia Dasar (Studi Era Darurat Covid 19)" Jurnal Bunayya, 1 (1): 53-68. http://jurnal.stit-alittihadiyahlabura.ac.id/index.php/bun ayya/article/view/62.

Dimyati dan Mudjiono, 2011. Belajar dan Pembelajaran. Jakarta. Rineka Cipta.

Djamarah, S.B. \& Zain, A. 2009. Strategi Belajar Mengajar. Jakarta: Rineka Cipta.

Djiwandono, SEW. 2008. Psikologi Pendidikan. Edisi Revisi. Jakarta: Grasindo Widiasarana Indonesia.

Hisyam, Z. 2007. Strategi Pembelajaran Aktif. Yogyakarta: CTSD (Center for Teaching Staff Development.

Indianto, Dimas, 2019, Pendidikan Agama Islam Dalam Revolusi Industri 4.0, Prosiding Seminar Nasional Prodi PAI, UMP, Vo. 1(1). 2019.

Istarani, 2011. Model Pembelajaran Inovatif. Medan: Mediapersada.
Lie, A,. 2008. Mempraktekkan Cooperative Learning di Ruang-Ruang Kelas. Jakarta: Grasindo.

Pingge, Heronimus Delu \& Muhammad Nur Wangid. 2015. "Faktor yang Mempengaruhi Hasil Belajar Siswa Sekolah Dasar di Kecamatan Kota Tambolaka" Jurnal Pendidikan Sekolah Dasar Abmad Dablan, 2 (1): 107-122.

Roestiyah. 2009. Strategi Belajar Mengajar, Jakarta: Rineka Cipta.

Sanjaya, W. 2008. Strategi Pembelajaran Berorientasi Standar Proses Pendidikan. Jakarta: Kencana..

Satriawati, Gusni, et.al. 2018. "Pengaruh Strategi Pembelajaran Active Knowledge Sharing Terhadap Kemampuan Komunikasi Matematik Siswa" Jurnal Riset Pendidikan Matematika Jakarta, 1 (1). http://journal.unj.ac.id/unj/index.ph $\mathrm{p} / \mathrm{jrpmj} /$ article/view/4961.

Sillberman, Melvin L., 2009. Active Learning. 1001 Strategi Pembelajaran Aktif, Yogyakarta: Pustaka Insan Madani.

Slameto. 2008. Belajar dan Faktor-Faktor yang Mempengarubinya. Jakarta: Rineka Cipta

Sudjana, 2008, Proses Belajar Mengajar. Bandung Tarsito.

Sudijono, Anas. 2008. Pengantar Statistik Pendidikan, Jakarta: Raja Grafindo Persada.

Tambak, Syahraini. 2014. "Metode Ceramah: Konsep dan Aplikasi dalam Pembelajaran Pendidikan Agama Islam”, Jurnal Tarbiyah, 21 (2). http://dx.doi.org/10.30829/tar.v21i2. 16. 
Trianto. 2010. Model Pembelajaran Terpadu. (Konsep, Strategi, dan Implementasi dalam Kurikulum Tingkat Satuan Pendidikan), Jakarta: Bumi Aksara.

Uno, H. B., 2009, Model Pembelajaran Menciptakan Proses Belajar Mengajar yang Kreatif dan Efektif, Jakarta: Bumi Aksara

Winkel W.S., 2008, Psikologi Pendidikan dan Evaluasi Belajar, Edisi Revisi, Gramedia, Jakarta 